\title{
Penggunaan Metode Pemecahan Masalah Sistematis (Systematic Approach to Problem Solving) untuk Meningkatkan Hasil Pembelajaran pada Tema Getaran dan Gelombang Siswa Kelas VIII-A SMP Negeri 3 Ngimbang Lamongan
}

\author{
ZAMRONI \\ Email : zamroni.roni67@gmail.com
}

\begin{abstract}
Abstrak :
Untuk meningkatkan hasil pembelajaran siswa kelas VIII A pada tema getaran dan gelombang dilakukan Penelitian Tindakan Kelas. Tujuan yang ingin dicapai dari penelitian ini adalah upaya menjelaskan atau meningkatkan keaktivan siswa melalui penggunaa metode pemecahan massalah sistematis (Systematic Approach to Problem Solving), upaya meningkatkan hasil belajar pada siswa melalui penggunaa metode pemecahan massalah sistematis (Systematic Approach to Problem Solving). Penelitian ini terdiri dari dua siklus dengan menggunakan teknik analisis data deskriptif kuantitatif dan kualitatif, melalui tahap perencanaan, pelaksanaan tindakan dan observasi, serta refleksi. Pengumpulan data dibantu teman sejawat sebagai kolaborator melalui instrumen observasi untuk mengamati aktivitas guru dan siswa, instrumen angket untuk mengetahui respon siswa setelah mendapatkan pembelajaran, dan soal tes tulis untuk mengetahui hasil belajar siswa. Hasil penelitian menunjukkan bahwa, aktivivas siswa terhadap pembelajaran dengan metode pemecahan massalah sistematis (Systematic Approach to Problem Solving) mengalami Dengan demikian dapat disimpulkan bahwa keaktivan siswa berada pada kategori aktif, ketuntasan hasil belajar siswa mengalami peningkatan setelah menggunakan metode pemecahan masalah sistematis (Systematic Approach to Problem Solving)
\end{abstract}

Kata kunci: Hasil Pembelajaran, pemecahan massalah sistematis (Systematic Approach to Problem Solving)

\section{Pendahuluan}

Proses interaksi peserta didik dengan pendidik dan sumber belajar dalam suatu lingkungan belajar merupakan bagian dari kegiatan pendidikan. Sebagai pendekatan utama memahami pendidikan adalah UndangUndang Nomor 20 tahun 2003 tentang 
Pasal 1, ayat (1) dikemukakan bahwa pendidikan adalah usaha sadar dan terencana untuk mewujudkan suasana belajar dan proses pembelajaran agar peserta didik secara aktif mengembang- kan potensi dirinya untuk memiliki kekuatan spiritual keagamaan, pengen- dalian diri, kepribadian, kecerdasan, akhlak mulia, serta keterampilan yang 
diperlukan dirinya, masyarakat, bangsa dan negara.

Berkaitan dengan pengertian pendidikan menurut Undang-Undang Nomor 20 tahun 2003 tentang Sistem Pendidikan Nasional, terdapat beberapa implikasi dari makna yang dapat dikemukan yaitu (1) pendidikan merupakan usaha sadar (2) pendidikan harus dilakukan secara terencana (3) pendidikan harus dapat mewujutkan suasana belajar dan proses pembelajaran yang kondusif (4) pendidikan harus melibatkan peserta didik untuk aktif mengembangkan potensi dirinya (5) pendidikan harus mengarahkan peserta didik untuk memiliki kekuatan spiritual keagamaan, pengendalian diri, kepribadian, kecerdasan, akhlak mulia, serta keterampilan diperlukan dirinya, masyarakat, bangsa dan negara.

Sebuah proses pendidikan, baik di tingkat nasional maupun pada tingkatan kelas akan dianggap sukses apabila kompetensi lulusan yang ditargetkan dapat tercapai. Untuk itu diperlukan tahapan-tahapan dan serangkaian strategi yang dijadikan pedoman untuk mencapai target tersebut. Standar proses merupakan sebuah pedoman, atau langkah-langkah bagi pendidik pada saat memberikan pembelajaran dalam kelas dengan harapan proses pembelajaran yang berlangsung bisa efektif dan inovatif sehingga target dan kriteria kompetensi lulusan dapat tercapai. Menurut Ridwan Abdullah Sani (2013), Kegiatan pembelajaran efektif pada umumnya meliputi aspek-aspek (1) berpusat pada peserta didik (student centered) (2) interaksi edukatif antara guru dan siswa (3) suasana demokratis (4) variasi metode mengajar (5) bahan yang sesuai dan bermanfaat lingkungan yang kondusif (7) sarana belajar yang menunjang.

Untuk menunjang pelaksanaan pembelajaran efektif diperlukan strategi pembelajaran. Penggunaan strategi dalam kegiatan pembelajaran sangat perlu karena untuk mempermudah proses pembelajaran sehingga dapat mencapai hasil yang optimal. Tanpa strategi yang jelas proses pembelajaran tidak akan terarah sehingga tujuan pembelajaran yang telah ditetapkan sulit tercapai secara optimal, dengan kata lain pembelajaran tidak dapat berlangsung secara efektif dan efisien (Made Wena, 2010: 2-3).

Strategi pembelajaran pada dasarnya adalah suatu rencana untuk mencapai tujuan, terdiri dari metode, teknik, dan prosedur yang mampu menjamin peserta didikbenar-benar akan mencapai tujuan akhir kegiatan pembelajaran (Hamzah B. Uno, Nurdin Muhamad, 2012: 6). Strategi pembelajarn merupakan rencana tindakan termasuk penggunaan metode dan pemanfaatan berbagai sumber daya dalam pembelajaran, strategi pembelajaran menentukan pendekatan yang dipilih guru untuk mencapai tujuan pembelajaran secara efektif dan efisien, strategi pembelajaran meliputi pendekatan, metode, dan teknik pembelajaran (Ridwan Abdullah Sani, 2013: 89).

Langkah operasional yang digunakan untuk menerapkan strategi 
pembelajaran yang dipilih adalah metode pembelajaran dalam rangka upaya mencapai tujuan pembelajaran. Metode pembelajaran lebih bersifat prosedural yaitu berisi tahapan-tahapan tertentu atau merupakan cara mengajar yang telah disusun berdasarkan prinsip dan sistem tertentu. Pada dasarnya tujuan akhir pembelajaran untuk menghasilkan siswa yang memiliki pengetahuan dan keterampilan atau kompetensi yang handal dalam memecahkan masalah yang dihadapi. Berdasarkan kajian beberapa literatur terdapat banyak metode pemecahan masalah yang kiranya dapat diterapkan dalam pembelajaran.

Dalam kasus pembelajaran di kelas peserta didik atau siswa belum mampu menggunakan segenap pengetahuan yang didapat untuk memecahkan masalah-masalah yang ada kaitannya dengan bidang studi yang dipelajari, tetapi baru terfokuskan pada mendapatkan pengetahuan sebanyakbanyaknya. Peserta didik atau siswa belum mampu berfikir secara prosedural, tahap demi tahap secara sistematis terutama pada persoalan pengetahuan yang berkaitan dengan perhitungan matematis seperti mata pelajaran ilmu pengetahuan alam. Sebagai contoh memacahkan masalah pada soal perhitungan matematis, menetukan data, menentukan atau menemukan persoalan yang dicari, dan menyelesaikan dengan formula atau rumus tertentu masih kesulitan dan kesalahan dalam memasukkan data ke dalam formula atau rumus, serta kesalahan memilih formula atau rumus itu sendiri. Untuk itu kemampuan pemecahan masalah sangat penting bagi siswa, metode pemecahan masalah dalam pembelajaran sangat diperlukan dengan memperhatikan jenis masalah yang ingin dipecahkan maka metode pemecahan masalah yang dipillih adalah metode pemecahan masalah sistematis (systematic approach to problem solving).

Berdasarkan uraian latar belakang di atas, maka permasalahan yang dibahas dalam penelitian ini dapat dirumuskan sebagai berikut (1) Bagaimanakah keaktivan siswa dalam penggunaan metode pemecahan masalah sistematis (Systematic Approach to Problem Solving) dengan tema getaran dan gelombang siswa kelas VIII A SMP Negeri 3 Ngimbang (2) Apakah penggunaan metode pemecahan masalah sistematis (Systematic Approach to Problem Solving) dapat meningkatkan hasil belajar siswa dengan tema getaran dan gelombang siswa kelas VIII A SMP Negeri 3 Ngimbang?.

\section{Metode}

Berdasarkan pendapat Lewin (Sujak, dalam Zainal Aqib, dkk, 2011: 145-146) penelitian tindakan kelas dirancang dengan langkah-langkah yang meliputi studi pendahuluan, persiapan tindakan, pelaksanaan tindakan, dan refleksi. Langkah-langkah tersebut dapat diuraikan sebagai berikut. Langkah awal kegiatan penelitian ini dimulai identifikasi permasalahan yang ada dalam pembelajaran, baik permasalahan 
yang ada dalam siswa, guru, maupun dalam proses perencanaan. Setelah itu, diadakan analisis hasil permasalahan dan diperoleh temuan. Berdasarkan temuan itu, peneliti bersama guru menyusun rencana tindakan. Rencana tindakan kelas berupa rencana pelaksanaan pembelajaran, penilaian, dan bahan atau materi yang digunakan dalam pembelajaran. Rencana tindakan itu dilaksanakan dalam siklus-siklus pembelajaran. Setelah selesai tindakan setiap siklus, peneliti dan guru mengadakan refleksi untuk menentukan dasar tindakan perbaikan pada pelaksanaan siklus berikutnya hingga tujuan penelitian tercapai. Berikutnya alur penelitian diuraikan pada bagian berikut ini

Subyek dalam penelitian ini adalah guru sebagai kolabaorator dan siswa kelas VIII A SMP Negeri 3 Ngimbang dengan jumlah 37 siswa. Kegiatan awal yang dilakukan peneliti sebelum melaksanakan penelitian tindakan kelas adalah dengan menyerap aspirasi siswa melalui kegiatan tanya jawab, hal ini perlu dilakukan peneliti karena melihat perkembangan pembelajaran selama ini didapatkan ketuntasan hasil belajaran sekitar $60 \%$, partisipasi aktif selama proses pembelajaran rendah atau mativasi rendah, belum menunjukkan pembelajaran yang menyenangkan. Siswa menginginkan stategi pembelajaran yang lebih bisa membangkitkan mativasi mereka dan guru belum bisa menyajikan pembelajaran yang menarik.

Berkaitan dengan tema getaran dan gelombang merupakan materi sangat erat kaitannya dengan perhitungan matematis terutama menetukan data, menemukan persoalan yang dicari, dan menyelesaikan dengan formula atau rumus tertentu masih kesulitan dan kesalahan dalam memasukkan data ke dalam formula atau rumus, serta kesalahan memilih formula atau rumus itu sendiri. Untuk itu kemampuan pemecahan masalah sangat penting bagi siswa, metode pemecahan masalah dalam pembelajaran sangat diperlukan dengan memperhatikan jenis masalah yang ingin dipecahkan maka metode pemecahan masalah yang dipillih adalah metode pemecahan masalah sistematis (systematic approach to problem solving).

Data penelitian ini berupa jenis data dan cara pengumpulan data. Jenis data meliputi data pelaksanaan pembelajaran dan data hasil belajar atau evaluasi. Data pelaksanaan pembelajaran diperoleh dengan cara pengamatan terhadap siswa dan guru selama proses pembelajaran dengan lembar observasi termasuk catatan hasil refleksi.. Jenis data hasil belajar atau evaluasi diperoleh juga saat proses pembelajaran diperoleh dengan cara memberikan tes tertulis kepada siswa.

Untuk membantu dalam melakukan analisis data, maka data yang diperoleh dapat dibagi dua yaitu data kualitatif dan data kuantitatif. Data yang bersifat kualitatif berupa catatan deskriptif, atau kalimat yang merekam sikap, respon, antusias, motivasi, kerja sama, percaya diri, menghargai, tanggapan, kegiatan siswa selama proses belajar dianalisis 
secara kualitatif. Data yang bersifat kuantitatif dianalisis secara deskriptif. Dari analisis ini dapat diperoleh misalnya berupa prosentase keberhasilan ketuntasan belajar siswa, nilai rata-rata tes atau ulangan harian (Sutirjo, 2009: 167). Data yang sifatnya kualitatif, berupa catata deskriptif atau kalimat yang merekam respon dan akltifitas dianalisis secara deskriptif yaitu respon siswa setelah siklus pembelajaran dan aktifitas siswa selama siklus pembelajaran, sedangkan analisis deskriptif statistik diperoleh berupa presentase keberhasilan atau ketuntasan belajar siswa ulangan atau evaluasi yaitu nilai hasil belajar siswa dalam mngejakan soal tes

Indikator keberhasilan penelitian tindakan kelas dikatakan berhasil apabila (1) keaktifan siswa dalam kegiatan pembelajaran mencapai keberhasilan sama dengan atau lebih dari $80 \%$ (2) ketuntasan hasil belajar siswa mencapai keberhasilan sama dengan atau lebih dari $80 \%$ dengan criteria ketuntasan minimal 70 .

\section{Hasil dan Pembahasan}

\section{Siklus I}

Siklus I dilaksankan selama dua kali pertemuan/tatap muka. Pada pertemuan pertama difakuskan pada kegiatan untuk mendeskripsikan konsep getaran, dan pada pertemuan kedua mendeskripsikan gelombang transversal dengan memecahkan soal secara sistematis melalui analisis soal, transformasi soal, operasi perhitungan, dan pengecekan dan interprestasi. Pada siklus I pengamatan aktivitas siswa diperoleh pada kegiatan inti yang meliputi aktifitas mengamati demontrasi, aktifitas diskusi kelompok untuk memecahkan soal dan masih dijumpai anggota kelompok yang kurang aktif berdiskusi baik pada pertemuan pertama maupun pertemuan kedua, aktivitas mencari informasi dengan membaca buku dan semua peserta didik sudah melakukan aktivitas membaca, aktivitas diskusi memecahkan soal secara sistematis didapatkan ratarata tiap kelompok ada satu anggota yang kurang aktif baik pada pertemuan pertama maupun kedua, semua aktifitas peserta didik atau kelompok sudah terlibat dalam membacakan, menyimak, tanggapan presentasi baik pada pertemuan pertama maupun kedua.

Dari presentasi didapatkan empat kelompok, yaitu kelompok 1, 2, 4, 6 masih belum benar menganalisis soal yaitu keliru/terbalik menulis besaran yang ditanyakan, belum benar mentransformasikan soal terutama tidak mengubah soal ke bentuk standar dengan tidak cocok menulis rumus yang memuat besaran yang ditanyakan, belum benar opersi perhitungan terutama tidak mengecek apakah tanda dan satuan sudah sesuai, belum melakukan pengecekan dan interprestasi terutama belum mengecek apakah jawaban sudah sesuai dengan yang ditanyakan serta belum menelusuri kesalahan-kesalah apa yang telah dilakukan. Lembar KR chart belum berfungsi dengan baik. 
Dari hasil pengamatan siklus I diperoleh hal-hal yang sudah berjalan dengan baik selama proses pembelajaran, yaitu menganalisis soal walaupun masih ada yang terbalik/keliru menuliskan satuan. Semua aktivitas peserta didik atau kelompok sudah terlibat dalam membacakan/menyimak/tanggapan presentasi

Sedangkan hal-hal yang belum berjalan dengan baik, yaitu mentransformasikan soal terutama menstandarkan soal, belum dapat menuliskan rumus mengenai besaran yang ditanyakan, KRchart belum berfungsi dengan baik hanya mencantumkan satu besaran saja, operasi perhitungan terutama belum satuan sudah ada yang belum sesuai, pengecekan dan interprestasi belum optimal dilakukan dengan mengecek apakah jawaban sudah sesuai dengan yang ditanyakan dan belum menelusuri kesalahan-kesalahan yang telah dilakukan. Aktivitas diskusi tahapan-tahapan pemecahan soal melalui lembar kegitan sekolah masih ditemukan anggota kelompok yang kurang aktif.

\section{Siklus II}

Siklus II dilaksankan selama dua kali pertemuan/tatap muka. Pada pertemuan pertama difokuskan pada kegiatan pemecahan masalah tentang gelombang longitudinal, dan pada pertemuan kedua pemecahan masalah tentang kecepatan rambat gelombang. Pada siklus II pengamatan aktivitas siswa diperoleh pada kegiatan inti yang meliputi aktivitas mengamati demontrasi, aktivitas diskusi kelompok untuk menyusun pertanyaan atau rumusan dan ada beberapa anggota yang aktif berdiskusi tapi kurang fokus baik pada pertemuan pertama maupun pertemuan kedua, aktivitas mencari informasi dengan membaca buku dan semua peserta didik sudah melakukan aktivitas membaca, aktivitas diskusi pemcahan masalah sistematis melalui analisis soal, transformasi soal, operasi perhitungan, pengecekan dan interprestasi didapatkan semua anggota kelompok sudah aktif karena masing-masing anggota sudah mendapatkan pembagian tugas baik pada pertemuan pertama maupun kedua, KR-chart sudah berfungsi dengan baik terbukti siswa mampu menuliskan rumus sesuai dengan besaran yang ditanyakan. Semua aktifitas peserta didik atau kelompok sudah terlibat dalam membacakan, menyimak, tanggapan presentasi baik pada pertemuan pertama maupun kedua. Dari presentasi didapatkan satu kelompok, yaitu kelompok 7 masih ada sedikit operasi perhitungan yang salah hal ini berarti pengecekan yang terburu-buru. Pada pertemuan kedua semua kelompok sudah benar dalam analisis soal, tranformasi soal, operasi perhitungan, pengecekan dan interprestasi. dan hasil pembelajaran diperoleh dari ulangan atau evaluasi melalui tes tertulis.

Dari hasil pengamatan siklus II diperoleh hal-hal yang sudah berjalan dengan baik selama proses pembelajaran dan semua anggota kelompok aktif diskusi analisis soal, tranformasi soal, operasi perhitungan, pengecekan dan interprestasi, semua aktifitas peserta 
didik atau kelompok sudah terlibat dalam membacakan, menyimak, tanggapan presentasi.

\section{Pembahasan}

Aktivitas peserta didik yang diamati adalah pada kegiatan inti yang meliputi lima aktivitas, yaitu aktivitas mengamati gambar, aktivitas diskusi menyusun pertanyaan atau rumusan dari hasil pengamatan, aktivitas mencari informasi dengan mambaca buku, aktivitas mengasosiasi dengan diskusi pemecahan masalah sistematis (Systematic Approach to Problem Solving), aktivitas menyampaikan informasi dengan membacakan/menyimak hasil pemecah-an masalah sistematis (Systematic Approach to Problem Solving). Pada siklus I, peserta didik yang melakukan lima aktivtas jumlahnya 23 peserta didik (62,16\%). Dua aktivitas yang masih ada peserta didik belum bisa berdiskusi yaitu diskusi menyusun pertanyaan atau rumusan terdapat ada 6 peserta didik dan diskusi pemecahan masalah sistematis (Systematic Approach to Problem Solving) ada 8 peserta didik sehingga kategori kurang aktif ada 14 peserta didik $(37,83 \%)$. Perubahan jumlah kelompok tidak, tetapi dilakukan pembagian tugas/peran setiap anggota kelompok yang bertujuan untuk mengefektifkan pelaksanaan diskusi kelompok.

Pada siklus II, pembagian tugas/peran setiap anggota kelompok tampaknya membawa perubahan lebih efektif dimana peserta didik yang melakukan lima aktivitas jumlahnya meningkat menjadi 31 peserta didik
$(83,78 \%)$ berarti pada kategori aktif. Sedangkan 6 peserta didik $(16,21 \%)$ yang tidak fokus dalam diskusi kelompok menyusun pertanyaan atau rumusan tetapi untuk diskusi pemecahan masalah sistematis (Systematic Approach to Problem Solving) lebih efektif karena setiap anggota kelompok mempunyai tugas/peran masing-masing..

Dalam penelitian ini keaktifan peserta didik selama mengikuti pembelajaran dengan menggunakan kartu mengalami meningkatan dari siklus I dan siklus II sebesar 21,62 \%.

\begin{tabular}{|c|c|c|c|c|c|}
\hline \multirow[b]{2}{*}{$\begin{array}{l}\mathrm{N} \\
\mathrm{o}\end{array}$} & \multirow[b]{2}{*}{ Aktifitas } & \multicolumn{2}{|c|}{$\begin{array}{l}\text { Jumlah } \\
\text { Siklus I }\end{array}$} & \multicolumn{2}{|c|}{$\begin{array}{l}\text { Jumlah } \\
\text { Siklus II }\end{array}$} \\
\hline & & $\begin{array}{c}\text { Sena } \\
\text { ng }\end{array}$ & $\begin{array}{c}\text { Kura } \\
\text { ng } \\
\text { Aktif }\end{array}$ & $\begin{array}{c}\text { Sena } \\
\text { ng }\end{array}$ & $\begin{array}{c}\text { Kura } \\
\text { ng } \\
\text { Aktif }\end{array}$ \\
\hline 1 & $\begin{array}{l}\text { Aktifitas } \\
\text { mengamati, } \\
\text { menanya, } \\
\text { mengumpulk } \\
\text { an informasi, } \\
\text { mengasosiasi, } \\
\text { mengkomuni } \\
\text { kasikan } \\
\text { a. Lima } \\
\text { aktifitas } \\
\text { b. Kurang dari } \\
\text { lima } \\
\text { aktifitas }\end{array}$ & 23 & 14 & 31 & 6 \\
\hline & Jumlah & 23 & 14 & 31 & 6 \\
\hline & Prosentase & 62,16 & 37,83 & 83,78 & 16,21 \\
\hline
\end{tabular}

Tabel 1 : Aktifitas siswa terhadap pembelajaran dengan Pemecahan Masalah Sistematis (Systematic Approach to Problem Solving)

Ketuntasan hasil belajar diperoleh dari hasil ulangan atau evaluasi. Siklus I, jumlah peserta didik yang mendapatkan nilai memenuhi KKM ada 22 peserta didik, sedangkan jumlah peserta didik yang mendapatkan nilai belum memenuhi KKM ada 15 peserta didik, hal ini berarti ketuntasan belajar peserta didik 
baru 59,45 \%. Pada siklus II, jumlah peserta didik yang mendapatkan nilai yang memenuhi KKM mengalami peningkatan yaitu 30 peserta didik dan jumlah peserta didik yang tidak memenuhi KKM ada 5 peserta didik. Hal ini berarti ketuntasan belajar peserta didik $81,08 \%$

Dalam penelitian ini ketuintasan belajar peserta didik dalam pembelajaran dengan pemecahan masalah sistematis (Systematic Approach to Problem Solving) mengalami meningkatan dari siklus I dan siklus II sebesar 21,63\%

\begin{tabular}{|c|c|c|c|c|c|}
\hline \multirow{2}{*}{ No } & \multirow{2}{*}{$\begin{array}{c}\text { Hasil } \\
\text { Pembelajaran }\end{array}$} & \multicolumn{2}{|c|}{$\begin{array}{c}\text { Jumlah } \\
\text { Siklus I }\end{array}$} & \multicolumn{2}{c|}{ Jumlah Siklus } \\
\cline { 3 - 6 } & & $\mathrm{T}$ & $\mathrm{TT}$ & $\mathrm{T}$ & $\mathrm{TT}$ \\
\hline 1 & $\begin{array}{l}\text { Ketuntasan } \\
\text { belajar }\end{array}$ & 22 & 15 & 30 & 7 \\
\hline \multicolumn{2}{|c|}{ Jumlah } & 22 & 15 & 30 & 7 \\
\hline Prosentase & 59,45 & 40,54 & 81,08 & 18,91 \\
\hline
\end{tabular}

Tabel 2 : Ketuntasa pembelajaran siswa dengan Pemecahan Masalah Sistematis (Systematic Approach to Problem Solving)

Hal ini sejalan dengan penelitian yang dilakukan oleh Andhini (2011), Afriyola Saputra, Djusmaini Djamas, Yulkifli (2013), Ida Ayu Wayan Wedika Santhi (2014) metode Pemecahan Massalah Sistematis (Systematic Approach to Problem Solving) dapat meningkatkan hasil pembelajaran peserta didik.

\section{Kesimpulan}

Berdasarkan temuan hasil penelitian, simpulan dalam penelitian ini adalah (1) keaktivan siswa dalam pembelajaran dengan penggunaan metode pemecahan massalah sistematis (Systematic Approach to Problem Solving) dengan tema getaran dan gelombang pada siklus I maupun siklus II penelitian tindakan kelas ini berada pada kategori aktif (3) ketuntasan hasil belajar siswa dalam pembelajaran dengan tema getaran dan gelombang mengalami peningkatan peningkatan setelah menggunakan metode pemecahan massalah sistematis (Systematic Approach to Problem Solving)

\section{Daftar Pustaka}

Andhini, (2011). Penggunaan Metode Pemecahan Masalah Ssistematis (Systematic Approach to Problem Solving) Untuk Meningkatkan hasil belajar Matematika Pada Siswa Kelas IV SD Negeri Pakah 01 Ngawi Tahun Pelajaran 2011/2012. online. eprints.ums.ac.id.

Afriyola Saputra, Djusmaini Djamas, Yulkifli (2013). Pengaruh Strategi Pemecahan Masalah Ssistematis (Systematic Approach to Problem Solving) Berbantuan Solution Parh Outline (SPO) Terhadap hasil belajar Fisika Siswa Kelas $X$ SMAN 2 Batang Kapas. Online.

ejournal.unp.ac.id.

Aqib, Zainal, dkk. 2011. Penelitian Tindakan Kelas Untuk Guru SMP, 
SMA, SMK, Bandung : Yrama Yidya.

Ida Ayu Wayan Wedika Santhi, (2014). Peningkatan Prestasi Belajar Melalui Metode Pemecahan Masalah Sistenatis Pada Kelas VB SDN Cakranegara Kota Mataram. online. unmasmataram.ac.id

Sagala, Syaiful. 2011. Konsep dan Makna Pembelajaran Untuk Membantu Memecahkan Problematika Belajar dan Mengajar. Bandung : Alfabeta.

Sani, Ridwan Abdullah. 2013. Inovasi Pembelajaran. Jakarta : Bumi Aksara
Sukmadinata, Nana Syaodih. 2010. Metode Penelitian Pendidikan. Bandung : PT. Remaja Rosdakarya.

Sutirjo. 2009. Menulis PTK Senikmat Minum Teh Langkah Demi Langkah Menyusun PTK. Malang : UM Press

Uno, Hamzah B, Mohamad, Nurdin. 2012. Belajar dengan Pendekatan PAIKEM. Jakarta : Bumi Aksara.

Wena, Made. 2010. Strategi Pembelajaran Inovatif Konteporer Suatu Tinjauan Konseptual Operasional. Jakarta : Bumi Aksara 